\title{
Accident Analysis and Blackspot Identification at Chandrapur City
}

\author{
Dipali R. Khamankar ${ }^{1}$, Dr. Prashant Y. Pawade'2, Dr. Bhalchandra V. Khode ${ }^{3}$ \\ ${ }^{1} \mathrm{M}$. Tech, Transportation Engineering, Department of Civil Engineering, G H Raisoni College of Engineering, Nagpur \\ University, Maharashtra, India \\ ${ }^{2}$ Professor, Department of Civil Engineering, G H Raisoni College of Engineering, Nagpur University, Maharashtra, India \\ ${ }^{3}$ Professor, Department of Civil Engineering, G H Raisoni College of Engineering, Nagpur University, Maharashtra, India
}

Article Info

Volume 8, Issue 2

Page Number : 428-439

\section{Publication Issue}

March-April-2021

\section{Article History}

Accepted : 12 April 2021

Published : 18 April 2021

\section{ABSTRACT}

Increased economic activity raised the consumption levels of the people across the India. This created scope for increase in the travel and transportation demanding a greater number of vehicles. The increase in the vehicles since last ten years has put a lot of pressure on the existing roads and ultimately resulting in increased rate of accidents. Blackspots are occurred at urban areas due to increased rate of vehicles, shorter width of roads and defective geometry of intersections. Blackspots are the locations in the city where the accident rate observed to be high. Therefore, there is need identify such locations of the urban area. For the present research, Chandrapur city in Maharashtra, India was selected. Accident data of last four year (2015- 2018) was obtained from police station. Weighted severity index (WSI) method and statistical analysis is used for identifying the accident blackspots. After field observations and interaction with the public, some improvements are suggested for improving the accident blackspot.

Keywords : Severity Index, Accident Blackspot, Chi-Square Test

\section{INTRODUCTION}

Increased economic activity raised the consumption levels of the people across the country. This created scope for increase in the travel and transportation. The increased in the vehicles since last 10 years has put a lot of pressure on the existing roads and ultimately resulting in road accidents. A major social problem- the loss of lives through road accidents has created due to the spectacular increase in the number of motor vehicles on the road. The appealing human misery and the serious economic loss caused by road accidents demand the attention of the society and call for the solution for the problem. Understanding the problem and providing the solution shall be provided by the multi- disciplinary approach.

Chandrapur city is located in the south-central region of India in Maharashtra state. Chandrapur has approx. population of 3.75 lakhs. Also, the city having super thermal power station, the largest one in India. Also, the city is enriched with different minerals. The 
population of Chandrapur city has increased so far in this year and with that has increased the vehicles causing high traffic volume \& rise in pollution. But the transportation system in Chandrapur city is still the same. Blackspots are occurred at urban areas due to increased rate of vehicles, shorter width of roads and defective geometry of intersections. Blackspots are the locations in the city where the accident rate observed to be high. There is a need to carry out some work in the Chandrapur city to improve black spots for reducing the accident. Therefore, Chandrapur city is selected as a study area. The objective of the research is,

A. Statistical analysis of the accident data using Chsquare test.

B. To identify the accident black spot using weighted severity index (WSI) method.

C. Suggesting the improvements for the accident black spots.

Last four years (2015-2018) of accident data collected from Ram Nagar Police Stations. Weighted Severity Index (WSI), a scientific method is used for identifying the accident black spots. Statistical analysis has carried out for the collected data using Chi-Square Test to determine the independence of accidents with other attributes. Chi-Square Goodness of fit test conducted for test whether the accidents are occurring by chance or following any pattern. WSI values are determined for the 143 locations. The Locations with high WSI are treated as accident black spots. 10 black spots are taken for field study. After field observations and interaction with the public, some improvements are suggested for improving the accident black spots.

There is no relationship between the severity of accidents and the other attributes like month, season, day, hours in day and the age group except type of vehicle. Road accidents are distributed throughway the Year, Month and Season. Road accidents are not distributed throughout the day.

\section{DATA COLLECTION}

Accident data of last four years, from 2015 to 2018 was collected from Ram Nagar police station in Chandrapur city. The study area includes total 14 intersections namely Junona square, Bangali Camp square, Bagla Chowk, GEC square, Priyadarshani square, Bus Stop square, Anchaleshwar Gate, Chota Bazar square, Traffic Office square, Jayant Talkies square, Ram Nagar Police Station square, Jatpura Gate, Girnar square, Gandhi square. The data is summarized as follows

TABLE I. ACCIDENT DATA (2015 TO 2018)

\begin{tabular}{|c|c|c|c|c|c|}
\hline \multirow[b]{2}{*}{$\begin{array}{c}\text { Yea } \\
\mathbf{r}\end{array}$} & \multicolumn{4}{|c|}{ Type of Accident } & \multirow[b]{2}{*}{$\begin{array}{c}\text { Number } \\
\text { of } \\
\text { Accident } \\
\text { s }\end{array}$} \\
\hline & $\begin{array}{l}\text { Fata } \\
1(\mathrm{~K})\end{array}$ & $\begin{array}{c}\text { Grievou } \\
\text { s Injury } \\
\text { (GI) }\end{array}$ & $\begin{array}{c}\text { Mino } \\
\mathbf{r} \\
\text { Injur } \\
\mathbf{y} \\
(\mathrm{MI})\end{array}$ & $\begin{array}{c}\text { Dame to } \\
\text { Propert } \\
y\end{array}$ & \\
\hline $\begin{array}{c}201 \\
5\end{array}$ & 0 & 0 & 50 & 1 & 51 \\
\hline $\begin{array}{c}201 \\
6\end{array}$ & 12 & 45 & 45 & 11 & 113 \\
\hline $\begin{array}{c}201 \\
7\end{array}$ & 24 & 01 & 49 & 07 & 81 \\
\hline $\begin{array}{c}201 \\
8\end{array}$ & 06 & 13 & 35 & 01 & 55 \\
\hline
\end{tabular}

\section{METHODOLOGY}

\section{A. Statistical Analysis of Accident Data}

The causes for accidents being interplay of a variety of factors, the analysis of accident presents formidable problems. Qualitative methods of analysis of accidents can provide insight into the causes that contributed to the accident and can often help to identify the black 
spots on the street system. More recently, the emphasis has shifted to the application of statistical techniques in planning and analyzing experiments into the effectiveness of accident prevention measures. The data gathered on accidents can be purposefully interpreted and used only if modern statistical methods are employed. A number of statistical methods are currently being applied in accident research. These include

\section{i.Regression Method \\ ii.Poisson Distribution}

iii.Use of Chi- Squared test

iv.Quality Control Method

\section{B. Use of Chi-Square Method}

One of the situations a traffic engineer has to assess frequently is whether the safety measures adopted at a particular location or stretch of road have been really effective in reducing the number of accidents. Before and after data can be evaluated on statistical principles, and one of the handy tools in this direction is the Chi-Squared test. Let $\mathrm{b}$ be the no. of accidents before the improvements at a particular location and the number after the improvements. Assuming that the improvements have no effect and the accident number is expected to increase due to the changes in traffic and weather than let $\mathrm{b}$. $\mathrm{C}$ be the number of accidents expected if no improvement had been carried out, the factor $\mathrm{C}$ being called the control ratio. Then the value of Chi-Squared is,

$$
\mathrm{X}^{2}=(\mathrm{a}-\mathrm{b} \mathrm{C})^{2} /(\mathrm{a}+\mathrm{b}) \mathrm{C}
$$

The null hypothesis $\mathrm{H}_{0}$ stipulates that there is no real change due to the improvements.

Assuming a 5\% level of significance, from Table. We find the value of $x^{\wedge} 2$ to be 3.841 with one degree of freedom. If $\mathrm{x}^{2}>3.841$, we observe that the null hypothesis is unlikely to be true and that there is a real change. On the other hand, if $\mathrm{x}^{2}<3.841$, we conclude that the null hypothesis is true and that there is no real change due to the improvements.

The chi-squared $\left(\mathrm{x}^{2}\right)$ test is a very useful statistical tool and has many applications. Of particular importance to the traffic engineer are the following:

i.Testing of proportions with contingency tables.

ii.Goodness-of-fit-test

The probability density function for chi-squared distribution is shown in a graphical form. It will be seen that corresponding to each "degree of freedom" there is a definite curve.

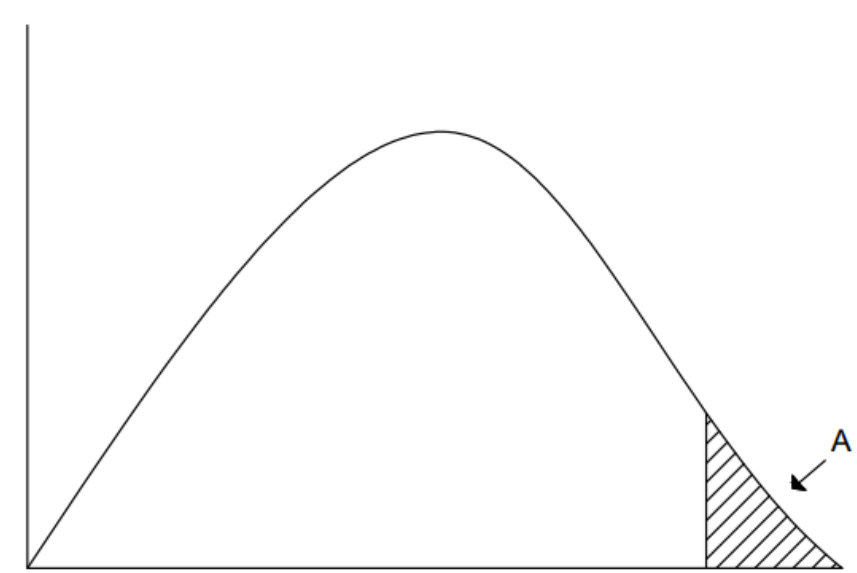

$\times 2$

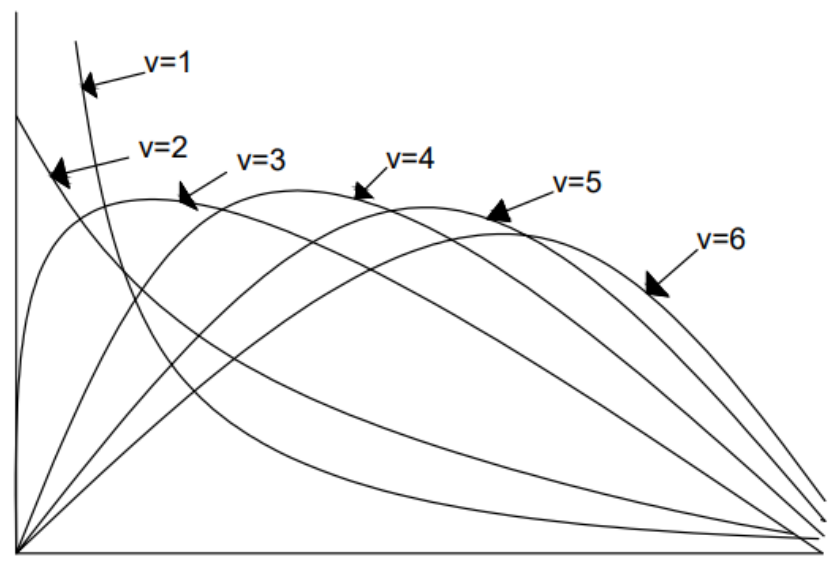

$x 2$

Fig.1. Distribution of $\mathrm{X}^{2}$ for various degree of freedom 
Dipali R. Khamankar et al Int J Sci Res Sci \& Technol. March-April-2021, 8 (2) : 428-439

\section{A. Chi-square test for independence of attribute}

i. Test of independence between the accident severity and the months in a year

TABLE II

TEST OF INDEPENDENCE BETWEEN THE ACCIDENT SEVERITY AND THE MONTHS IN A YEAR

\begin{tabular}{|c|c|c|c|c|c|c|c|c|c|c|c|}
\hline \multirow[t]{2}{*}{ Month } & \multicolumn{2}{|c|}{ Fatal } & \multicolumn{2}{|c|}{ Grievous Injury } & \multicolumn{2}{|c|}{ Minor Injury } & \multicolumn{2}{|c|}{ Damage to Property } & \multirow[t]{2}{*}{ Total } & \multirow{2}{*}{$\begin{array}{c}\text { Calculated } \\
\mathrm{X}^{2} \\
\end{array}$} & \multirow{2}{*}{$\begin{array}{c}\text { Critical } \\
\mathrm{X}^{2}\end{array}$} \\
\hline & Observed & Expected & Observed & Expected & Observed & Expected & Observed & Expected & & & \\
\hline Jan & 13 & 10.16 & 16 & 17.14 & 26 & 29.31 & 5 & 3.39 & 60 & \multirow{13}{*}{35.76} & \multirow{13}{*}{47.4} \\
\hline Feb & 12 & 10.16 & 14 & 17.14 & 32 & 29.31 & 2 & 3.39 & 60 & & \\
\hline Mar & 14 & 11.17 & 24 & 18.86 & 24 & 32.24 & 4 & 3.72 & 66 & & \\
\hline April & 10 & 9.31 & 18 & 15.71 & 24 & 26.87 & 3 & 3.1 & 55 & & \\
\hline May & 6 & 7.11 & 7 & 12 & 26 & 20.52 & 3 & 2.37 & 42 & & \\
\hline Jun & 9 & 8.63 & 13 & 14.57 & 27 & 24.92 & 2 & 2.88 & 51 & & \\
\hline July & 11 & 8.47 & 17 & 14.29 & 21 & 24.43 & 1 & 2.82 & 50 & & \\
\hline Aug & 6 & 7.11 & 12 & 12 & 22 & 20.52 & 2 & 2.37 & 42 & & \\
\hline Sept & 5 & 5.42 & 9 & 9.14 & 14 & 15.63 & 4 & 1.81 & 32 & & \\
\hline Oct & 3 & 5.93 & 13 & 10 & 14 & 17.1 & 5 & 1.98 & 35 & & \\
\hline Nov & 3 & 5.76 & 10 & 9.71 & 21 & 16.61 & 0 & 1.92 & 34 & & \\
\hline Dec & 4 & 6.77 & 9 & 11.43 & 26 & 19.54 & 1 & 2.26 & 40 & & \\
\hline Total & 96 & 96 & 162 & 162 & 277 & 277 & 32 & 32 & 567 & & \\
\hline
\end{tabular}

Null Hypothesis $\left(\mathrm{H}_{0}\right)$ : The accident severity and months in a year are independent.

Result: The above table shows a calculated $\mathrm{x}^{2}$-value of 35.76 and a critical $\mathrm{x}^{2}$-value of 47.40 at 0.05 alpha Level for 33 Degree of Freedom. Since the calculated $x^{2}$-value is less than critical $x^{2}$. The null hypothesis, "The Accident severity and the months in a year are independent" is accepted. Thus, it indicates there is no relationship between the accident severity and the months in a year.

ii. Test of independence between the accident severity and season in a year

TABLE III

TEST OF INDEPENDENCE BETWEEN THE ACCIDENT SEVERITY AND THE SEASON IN A YEAR

\begin{tabular}{|c|c|c|c|c|c|c|c|c|c|c|c|}
\hline \multirow{2}{*}{ Season } & \multicolumn{2}{|c|}{ Fatal } & \multicolumn{2}{|c|}{ Grievous Injury } & \multicolumn{2}{|c|}{ Minor Injury } & \multicolumn{2}{|c|}{ Damage to Property } & \multirow{2}{*}{$\begin{array}{c}\text { Tota } \\
1\end{array}$} & \multirow[b]{2}{*}{$\begin{array}{c}\text { Calculate } \\
\mathrm{d} \mathrm{X}^{2}\end{array}$} & \multirow[b]{2}{*}{$\begin{array}{c}\text { Critica } \\
1 \mathrm{X}^{2}\end{array}$} \\
\hline & $\begin{array}{c}\text { Observe } \\
\mathrm{d}\end{array}$ & $\begin{array}{c}\text { Expecte } \\
\text { d }\end{array}$ & $\begin{array}{c}\text { Observe } \\
\mathrm{d}\end{array}$ & $\begin{array}{c}\text { Expecte } \\
\text { d }\end{array}$ & $\begin{array}{c}\text { Observe } \\
\mathrm{d}\end{array}$ & $\begin{array}{c}\text { Expecte } \\
\mathrm{d}\end{array}$ & $\begin{array}{c}\text { Observe } \\
\mathrm{d}\end{array}$ & $\begin{array}{c}\text { Expecte } \\
\text { d }\end{array}$ & & & \\
\hline $\begin{array}{c}\text { Summe } \\
\mathrm{r}\end{array}$ & 49 & 40.8 & 72 & 68.86 & 106 & 117.74 & 14 & 13.6 & 241 & 8.56 & 12.59 \\
\hline Rainy & 32 & 31.32 & 49 & 52.86 & 96 & 90.38 & 8 & 10.44 & 185 & & \\
\hline Winter & 15 & 23.87 & 41 & 40.29 & 75 & 68.88 & 10 & 7.96 & 141 & & \\
\hline Total & 96 & 96 & 162 & 162.01 & 277 & 277 & 32 & 32 & 567 & & \\
\hline
\end{tabular}

Null hypothesis $\left(\mathrm{H}_{0}\right)$ : The accident severity and the seasons in a year are independent.

Result: The above table shows a calculated $\mathrm{x}^{2}$-value of critical $\mathrm{x}^{2}$-value of 12.59 at 0.05 alpha level for 6 degree of freedom. Since the calculated $\mathrm{x}^{2}$-value is less than critical $\mathrm{x}^{2}$. The null hypothesis, "the accident severity and the season in a year are independent" is accepted. It indicates that there is no relationship between accident severity and session in a year.

iii. Test of independence between accident severity and days in a week

TABLE IV

TEST OF INDEPENDENCE BETWEEN THE ACCIDENT SEVERITY AND THE DAYS IN A WEEK

\begin{tabular}{|c|c|c|c|c|c|c|c|c|c|c|c|}
\hline \multirow{2}{*}{ Day } & \multicolumn{2}{|c|}{ Fatal } & \multicolumn{2}{|c|}{ grievous Injury } & \multicolumn{2}{|c|}{ Minor Injury } & \multicolumn{2}{|c|}{ Damage to Property } & \multirow{2}{*}{ Total } & \multirow{2}{*}{$\begin{array}{c}\text { Calculated } \\
\mathrm{X}^{2}\end{array}$} & \multirow{2}{*}{$\begin{array}{c}\text { Critical } \\
\mathrm{X}^{2}\end{array}$} \\
\hline & Observed & Expected & Observed & Expected & Observed & Expected & Observed & Expected & & & \\
\hline Mon & 21 & 15.7 & 24 & 25.43 & 40 & 43.48 & 4 & 5.02 & 89 & \multirow{5}{*}{17.07} & \multirow{5}{*}{28.87} \\
\hline Tue & 15 & 13.4 & 21 & 22 & 38 & 37.62 & 3 & 4.35 & 77 & & \\
\hline Wed & 9 & 11.17 & 21 & 18.86 & 33 & 32.24 & 3 & 3.72 & 66 & & \\
\hline Thu & 18 & 15.92 & 29 & 26.86 & 45 & 45.92 & 2 & 5.31 & 94 & & \\
\hline Fri & 12 & 12.19 & 18 & 20.57 & 37 & 35.17 & 5 & 4.06 & 72 & & \\
\hline
\end{tabular}


Dipali R. Khamankar et al Int J Sci Res Sci \& Technol. March-April-2021, 8 (2) : 428-439

\begin{tabular}{|c|c|c|c|c|c|c|c|c|c|} 
Sat & 11 & 13.54 & 18 & 22.86 & 45 & 39.08 & 6 & 4.51 & 80 \\
\hline Sun & 10 & 15.07 & 31 & 25.43 & 39 & 43.48 & 9 & 5.02 & 89 \\
\hline Total & 96 & 96 & 162 & 162 & 277 & 277 & 32 & 32 & 567 \\
\hline
\end{tabular}

Null hypothesis $\left(\mathrm{H}_{0}\right)$ : The accident severity and the days in a week are independent.

Result: The above table shows a calculated $\mathrm{x}^{2}$-value of 17.07 and critical $\mathrm{x}^{2}$-value of 28.87 at 0.05 alpha level for 18 degree of freedom. Since the calculated $\mathrm{x}^{2}$-value is less than critical $\mathrm{x}^{2}$. The null hypothesis, "The accident severity and the days in a week are independent" is accepted. It shows that there is no relationship between the accident severity and the days in a week.

iv. Test of independence between accident severity and hours in a day

TABLE $V$

TEST OF INDEPENDENCE BETWEEN THE ACCIDENT SEVERITY AND THE HOURS IN A DAY

\begin{tabular}{|c|c|c|c|c|c|c|c|c|c|c|c|}
\hline \multirow[b]{2}{*}{ Hour } & \multicolumn{2}{|c|}{ Fatal } & \multicolumn{2}{|c|}{ grievous Injury } & \multicolumn{2}{|c|}{ Minor Injury } & \multicolumn{2}{|c|}{ Damage to Property } & \multirow[b]{2}{*}{$\begin{array}{c}\text { Tota } \\
1\end{array}$} & \multirow[b]{2}{*}{$\begin{array}{c}\text { Calculated } \\
\mathrm{X}^{2}\end{array}$} & \multirow[b]{2}{*}{$\begin{array}{c}\text { Critical } \\
\mathrm{X}^{2}\end{array}$} \\
\hline & $\begin{array}{c}\text { Observe } \\
\mathrm{d}\end{array}$ & $\begin{array}{c}\text { Expecte } \\
\mathrm{d}\end{array}$ & $\begin{array}{c}\text { Observe } \\
\mathrm{d}\end{array}$ & $\begin{array}{c}\text { Expecte } \\
\mathrm{d}\end{array}$ & $\begin{array}{c}\text { Observe } \\
\mathrm{d}\end{array}$ & $\begin{array}{c}\text { Expecte } \\
\mathrm{d}\end{array}$ & $\begin{array}{c}\text { Observe } \\
\mathrm{d}\end{array}$ & $\begin{array}{c}\text { Expecte } \\
\text { d }\end{array}$ & & & \\
\hline $\begin{array}{l}12-01 \\
\text { Am }\end{array}$ & 1 & 1.69 & 2 & 2.86 & 7 & 4.89 & 0 & 0.56 & 10 & \multirow{20}{*}{63.95} & \multirow{20}{*}{89.39} \\
\hline $\begin{array}{c}01-02 \\
\mathrm{Am}\end{array}$ & 0 & 1.35 & 5 & 2.29 & 1 & 3.91 & 2 & 0.45 & 8 & & \\
\hline $\begin{array}{c}02-03 \\
\text { Am }\end{array}$ & 0 & 0.34 & 1 & 0.57 & 1 & 0.98 & 0 & 0.11 & 2 & & \\
\hline $\begin{array}{c}\text { 03-04 } \\
\text { Am }\end{array}$ & 1 & 0.68 & 1 & 1.14 & 2 & 1.95 & 0 & 0.23 & 4 & & \\
\hline $\begin{array}{c}\text { 04-05 } \\
\text { Am }\end{array}$ & 1 & 1.19 & 2 & 2 & 3 & 3.42 & 1 & 0.4 & 7 & & \\
\hline $\begin{array}{c}05-06 \\
\text { Am }\end{array}$ & 2 & 1.02 & 2 & 1.71 & 1 & 2.93 & 1 & 0.34 & 6 & & \\
\hline $\begin{array}{c}\text { 06-07 } \\
\text { Am }\end{array}$ & 2 & 2.03 & 4 & 3.43 & 6 & 5.86 & 0 & 0.68 & 12 & & \\
\hline $\begin{array}{c}07-08 \\
\text { Am }\end{array}$ & 4 & 4.06 & 8 & 6.86 & 11 & 11.72 & 1 & 1.35 & 24 & & \\
\hline $\begin{array}{c}\text { 08-09 } \\
\text { Am }\end{array}$ & 1 & 4.74 & 10 & 8 & 14 & 13.68 & 3 & 1.58 & 28 & & \\
\hline $\begin{array}{c}09-10 \\
\text { Am }\end{array}$ & 5 & 3.72 & 10 & 6.29 & 7 & 10.75 & 0 & 1.24 & 22 & & \\
\hline $\begin{array}{c}10-11 \\
\text { Am }\end{array}$ & 5 & 3.72 & 5 & 6.29 & 10 & 10.75 & 2 & 1.24 & 22 & & \\
\hline $\begin{array}{c}11-12 \\
\text { Am }\end{array}$ & 4 & 4.4 & 8 & 7.43 & 13 & 12.7 & 1 & 1.47 & 26 & & \\
\hline $\begin{array}{l}12-01 \\
\mathrm{Pm}\end{array}$ & 2 & 3.05 & 5 & 5.14 & 10 & 8.79 & 1 & 1.02 & 18 & & \\
\hline $\begin{array}{c}\text { 01-02 } \\
\text { Pm }\end{array}$ & 5 & 4.23 & 5 & 7.14 & 14 & 12.21 & 1 & 1.41 & 25 & & \\
\hline $\begin{array}{c}02-03 \\
\text { Pm }\end{array}$ & 3 & 3.56 & 6 & 6 & 11 & 10.26 & 1 & 1.19 & 21 & & \\
\hline $\begin{array}{c}\text { 03-04 } \\
\text { Pm }\end{array}$ & 7 & 4.74 & 6 & 8 & 14 & 13.68 & 1 & 1.58 & 28 & & \\
\hline $\begin{array}{c}04-05 \\
\text { Pm }\end{array}$ & 6 & 7.28 & 9 & 1.29 & 26 & 21.01 & 2 & 2.43 & 43 & & \\
\hline $\begin{array}{c}05-06 \\
\text { Pm }\end{array}$ & 5 & 5.76 & 6 & 9.71 & 19 & 16.61 & 4 & 1.92 & 34 & & \\
\hline $\begin{array}{c}06-07 \\
\mathrm{Pm}\end{array}$ & 1 & 6.1 & 13 & 10.29 & 19 & 17.59 & 3 & 2.03 & 36 & & \\
\hline $\begin{array}{c}07-08 \\
\text { Pm }\end{array}$ & 11 & 10.33 & 19 & 17.43 & 30 & 29.8 & 1 & 3.44 & 61 & & \\
\hline
\end{tabular}


Dipali R. Khamankar et al Int J Sci Res Sci \& Technol. March-April-2021, 8 (2) : 428-439

\begin{tabular}{|c|c|c|c|c|c|c|c|c|c|}
$\begin{array}{c}08-09 \\
\text { Pm }\end{array}$ & 14 & 11.01 & 17 & 18.57 & 31 & 31.75 & 3 & 3.67 & 65 \\
\hline $\begin{array}{c}09-10 \\
\text { Pm }\end{array}$ & 2 & 3.01 & 8 & 6 & 8 & 10.26 & 3 & 1.19 & 21 \\
\hline $\begin{array}{c}10-11 \\
\text { Pm }\end{array}$ & 7 & 4.06 & 6 & 6.86 & 11 & 11.72 & 0 & 1.35 & 24 \\
\hline $\begin{array}{c}11-12 \\
\text { Pm }\end{array}$ & 7 & 3.39 & 4 & 5.71 & 8 & 9.77 & 1 & 1.13 & 20 \\
\hline Total & 96 & 96 & 162 & 162 & 277 & 277 & 32 & 32 & 567 \\
\hline
\end{tabular}

Null hypothesis $\left(\mathrm{H}_{0}\right)$ : The accident severity and the hour in a day are independent

Result: The above table shows a calculated $\mathrm{x}^{2}$-value of 63.950 And a critical $\mathrm{x}^{2}$-value of 89.391 at 0.05 alpha level for 69 degree of freedom. Since the calculated $\mathrm{x}^{2}$-value is less than critical $\mathrm{x}^{2}$. The null hypothesis, "The accident severity and the hour in a day are independent" is accepted. It shows that there is no relationship between the accident severity and the hours in a day.

v. Test of independence between accident severity and age group of drivers

TABLE VI

TEST OF INDEPENDENCE BETWEEN THE ACCIDENT SEVERITY AND AGE GROUP OF DRIVERS

\begin{tabular}{|c|c|c|c|c|c|c|c|c|c|c|c|c|}
\hline \multicolumn{2}{|c|}{ Age group } & \multicolumn{2}{|c|}{ Fatal } & \multicolumn{2}{c|}{ Grievous injury } & \multicolumn{2}{c|}{ Minor Injury } & \multicolumn{2}{c|}{ Damage to Property } & Total & $\begin{array}{c}\text { Calculated } \\
\mathrm{X}^{2}\end{array}$ & $\begin{array}{c}\text { Critical } \\
\mathrm{X}^{2}\end{array}$ \\
\hline From & To & Observed & Expected & Observed & Expected & Observed & Expected & Observed & Expected & \\
\hline 10 & 14 & 0 & 0.17 & 0 & 0.29 & 1 & 0.49 & 0 & 0.06 & 60 & \\
\hline 15 & 19 & 0 & 1.69 & 5 & 2.86 & 5 & 4.89 & 0 & 0.56 & 60 \\
\hline 20 & 24 & 9 & 9.31 & 15 & 15.71 & 26 & 26.87 & 5 & 3.1 & 66 \\
\hline 25 & 29 & 20 & 19.64 & 37 & 33.14 & 53 & 56.67 & 6 & 6.55 & 55 \\
\hline 30 & 34 & 20 & 19.81 & 26 & 33.43 & 64 & 57.16 & 7 & 6.6 & 42 \\
\hline 35 & 39 & 24 & 18.62 & 27 & 31.43 & 54 & 53.74 & 5 & 6.21 & 51 \\
\hline 40 & 44 & 11 & 10.33 & 16 & 17.43 & 30 & 29.8 & 4 & 3.44 & 50 \\
\hline 45 & 49 & 6 & 8.63 & 16 & 14.57 & 27 & 24.92 & 2 & 2.88 & 42 \\
\hline 50 & 54 & 3 & 3.05 & 8 & 5.14 & 6 & 8.79 & 1 & 1.02 & 32 \\
\hline 55 & 59 & 2 & 2.2 & 10 & 3.71 & 1 & 6.35 & 0 & 0.73 & 35 \\
\hline 60 & 64 & 1 & 1.35 & 0 & 2.29 & 6 & 3.91 & 1 & 0.45 & 34 \\
\hline 65 & 69 & 0 & 0.68 & 1 & 1.14 & 3 & 1.95 & 0 & 0.23 & 40 \\
\hline 70 & 74 & 0 & 0.51 & 1 & 0.86 & 1 & 1.47 & 1 & 0.17 & 41 \\
\hline \multicolumn{2}{|l|}{ TOTAL } & 96 & 96 & 162 & 162 & 277 & 277 & 32 & 32 & 567 \\
\end{tabular}

Null hypothesis $\left(\mathrm{H}_{0}\right)$ : The accident severity and the age group of drivers are independent.

Result: The above table shows a calculated $\mathrm{x}^{2}$-value of 42.20 and a critical $\mathrm{x}^{2}$-value of 50.99 at 0.05 alpha Level for 39 Degree of Freedom. Since the calculated $\mathrm{x}^{2}$-value is less than critical $\mathrm{x}^{2}$. The null hypothesis, "The Accident severity and the age group of drivers are independent" is accepted. It shows that there is no relationship between the accident severity and the age group of drivers.

vi. Test of independence between accident severity and types of vehicles

TABLE VI

TEST OF INDEPENDENCE BETWEEN THE ACCIDENT SEVERITY AND TYPE OF VEHICLES

\begin{tabular}{|c|c|c|c|c|c|c|c|c|c|c|c|}
\hline \multirow{2}{*}{$\begin{array}{l}\text { Type of } \\
\text { Vehicle }\end{array}$} & \multicolumn{2}{|c|}{ Fatal } & \multicolumn{2}{|c|}{ Grievous Injury } & \multicolumn{2}{|c|}{ Minor Injury } & \multicolumn{2}{|c|}{ Damage to Property } & \multirow{2}{*}{ Total } & \multirow{2}{*}{$\begin{array}{c}\text { Calculated } \\
\mathrm{X}^{2}\end{array}$} & \multirow[b]{2}{*}{$\begin{array}{c}\text { Critical } \\
\mathrm{X}^{2}\end{array}$} \\
\hline & Observed & Expected & Observed & Expected & Observed & Expected & Observed & Expected & & & \\
\hline $\begin{array}{c}\text { Motorised } \\
\text { Two- } \\
\text { Wheeler }\end{array}$ & 34 & 23.87 & 44 & 40.29 & 60 & 68.88 & 3 & 7.96 & 60 & \multirow{2}{*}{79.07} & \multirow{2}{*}{36.41} \\
\hline $\begin{array}{c}\text { Auto } \\
\text { Rikshaw }\end{array}$ & 22 & 32.85 & 60 & 55.43 & 109 & 94.78 & 3 & 10.95 & 60 & & \\
\hline
\end{tabular}


Dipali R. Khamankar et al Int J Sci Res Sci \& Technol. March-April-2021, 8 (2) : 428-439

\begin{tabular}{|c|c|c|c|c|c|c|c|c|c|} 
Van/Taxi & & & & & & & & \\
\hline Bus & 4 & 3.89 & 3 & 6.57 & 10 & 11.24 & 6 & 1.3 & 55 \\
\hline $\begin{array}{c}\text { Light } \\
\text { Truck }\end{array}$ & 7 & 7.62 & 16 & 12.86 & 12 & 21.98 & 10 & 2.54 & 42 \\
\hline $\begin{array}{c}\text { Heavy } \\
\text { Articulated } \\
\text { Truck }\end{array}$ & 10 & 6.26 & 6 & 10.57 & 20 & 18.08 & 1 & 2.09 & 51 \\
\hline $\begin{array}{c}\text { Tempo/ } \\
\text { Tractor }\end{array}$ & 9 & 6.43 & 8 & 10.86 & 19 & 18.56 & 2 & 2.14 & 50 \\
\hline Bicycle & 1 & 0.51 & 1 & 0.86 & 1 & 1.47 & 0 & 0.17 & 42 \\
\hline $\begin{array}{c}\text { Cycle } \\
\text { Rikshaw }\end{array}$ & 0 & 0.17 & 0 & 0.29 & 1 & 0.49 & 0 & 0.06 & 32 \\
\hline Total & 96 & 96 & 162 & 162 & 277 & 277 & 32 & 32 & 567 \\
\hline
\end{tabular}

Null hypothesis_( $\left.\mathrm{H}_{0}\right)$ : The accident severity and type of vehicles are dependent.

Result: The above tables shows a calculated $\mathrm{x}^{2}$-value of 79.078 and a critical $\mathrm{x}^{2}$-value of 36.415 at 0.05 alpha Level for freedom. Since the calculated $\mathrm{x}^{2}$-value is more than critical $\mathrm{x}^{2}$. The null hypothesis, "The accident severity and the type of vehicles are dependent" is rejected. It shows that there is some relationship between the accident severity and the type of vehicles.

B. Chi-square test for goodness of fit: Chandrapur city

i. Chi-square test for goodness of fit: monthly variation

TABLE VII

CHI-SQUARE TEST FOR GOODNESS OF FIT: MONTHLY VARIATION

\begin{tabular}{|c|c|c|c|c|c|}
\hline Month & Observed & Expected & DOF & Calculated X ${ }^{2}$ & Critical X ${ }^{2}$ \\
\hline Jan & 60 & 47.25 & \multirow{12}{*}{11} & 3.44 & \multirow{12}{*}{19.68} \\
\hline Feb & 60 & 47.25 & & 3.44 & \\
\hline Mar & 66 & 47.25 & & 7.44 & \\
\hline April & 55 & 47.25 & & 1.271 & \\
\hline May & 42 & 47.25 & & 0.583 & \\
\hline Jun & 51 & 47.25 & & 0.298 & \\
\hline July & 50 & 47.25 & & 0.16 & \\
\hline Aug & 42 & 47.25 & & 0.583 & \\
\hline Sep & 32 & 47.25 & & 4.922 & \\
\hline Oct & 35 & 47.25 & & 3.176 & \\
\hline Nov & 34 & 47.25 & & 3.716 & \\
\hline Dec & 40 & 47.25 & & 1.112 & \\
\hline Total & 567 & 567 & & 30.141 & Ho Rejected \\
\hline
\end{tabular}

Null hypothesis_( $\left.\mathrm{H}_{0}\right)$ : "Occurrence of accident is uniform throughout the year"

Result: The above table shows a calculated $\mathrm{x}^{2}$-value of 30.143 and a critical $\mathrm{x}^{2}$-value of 19.680 at 0.05 alpha level for 11 degree of freedom. Since the calculated $\mathrm{x}^{2}$-value is greater than critical $\mathrm{x}^{2}$. The null hypothesis, "occurrence of Accidents is uniform throughout the year" is rejected. Thus, it indicates that the accidents are not uniformly distributed throughout the year. Moreover, there is a lack of enough evidence to indicate such a monthly pattern.

ii. Chi-square test for goodness of fit: seasonal variation

TABLE VIII

CHI-SQUARE TEST FOR GOODNESS OF FIT: SEASONAL VARIATION

\begin{tabular}{|c|c|c|c|c|c|}
\hline Season & Observed & Expected & DOF & Calculation $\mathrm{X}^{2}$ & Critical X ${ }^{2}$ \\
\hline Summer & 241 & 189 & \multirow{3}{*}{2} & 14.307 & \multirow{3}{*}{5.99} \\
\hline Rainy & 185 & 189 & & 0.085 & \\
\hline Winter & 141 & 189 & & 12.19 & \\
\hline Total & 567 & 567 & & 26.582 & Ho rejected \\
\hline
\end{tabular}

Null hypothesis $\left(\mathrm{H}_{0}\right)$ : "Occurrences of accidents is uniform throughout the seasons" 
Result: The above table shows a calculated $\mathrm{x}^{2}$-value of 26.582 and a critical $\mathrm{x}^{2}$-value of 5.99 at 0.05 alpha level for 2 degree of freedom. Since the calculated $\mathrm{x}^{2}$-value is greater than critical $\mathrm{x}^{2}$. The null hypothesis, "occurrence of Accident is uniform throughout the season" is rejected. Thus, it indicates that the accidents are not uniformly distributed throughout the season. Moreover, there is a lack of enough evidence to indicate such a seasonal pattern.

iii. Chi-square test for goodness of fit: daily variation

TABLE IX

CHI-SQUARE TEST FOR GOODNESS OF FIT: DAILY VARIATION

\begin{tabular}{|c|c|c|c|c|c|}
\hline Day & Observed & Expected & DOF & Calculated X & Critical X $\mathrm{X}^{2}$ \\
\hline Mon & 89 & 81 & \multirow{7}{*}{6} & 0.79 & \multirow{7}{*}{12.59} \\
\hline Tue & 77 & 81 & & 0.198 & \\
\hline Wed & 66 & 81 & & 2.778 & \\
\hline Thu & 94 & 81 & & 2.086 & \\
\hline Fri & 72 & 81 & & 1 & \\
\hline Sat & 80 & 81 & & 0.012 & \\
\hline Sun & 89 & 81 & & 0.79 & \\
\hline Total & 567 & 567 & & 7.654 & Ho accepted \\
\hline
\end{tabular}

Null hypothesis_( $\left.\mathrm{H}_{0}\right)$ : "Occurrence of accidents is uniform throughout the week"

Result: The above table shows a calculated $\mathrm{x}^{2}$-value of 7.654 and a critical $\mathrm{x}^{2}$-value of 12.590 at 0.05 alpha level for 6 degree of freedom. Since the calculated $\mathrm{x}^{2}$-value is less than critical $\mathrm{x}^{2}$. The null hypothesis, "Occurrence of accident is uniform throughout the week" is accepted. Thus, it indicates that the accident is uniformly distributed throughout the week.

iv. Chi-square test for goodness of fit: hourly variation

TABLE X

CHI-SQUARE TEST FOR GOODNESS OF FIT: HOURLY VARIATION

\begin{tabular}{|c|c|c|c|c|c|}
\hline Time Duration & Observed & Expected & DOF & Calculated X ${ }^{2}$ & Critical X ${ }^{2}$ \\
\hline $12.00 \mathrm{am}$ to $06.00 \mathrm{am}$ & 37 & 141.75 & \multirow{4}{*}{3} & 77.408 & \multirow{4}{*}{7.81} \\
\hline $06.00 \mathrm{am}$ to $12.00 \mathrm{pm}$ & 134 & 141.75 & & 0.424 & \\
\hline $12.00 \mathrm{pm}$ to $06.00 \mathrm{pm}$ & 169 & 141.75 & & 5.239 & \\
\hline $06.00 \mathrm{pm}$ to $12.00 \mathrm{am}$ & 227 & 141.75 & & 51.27 & \\
\hline Total & 567 & 567 & & 134.34 & Ho rejected \\
\hline
\end{tabular}

Null hypothesis_(Ho): "Occurrence of accident is uniform throughout the day"

Result: The above table shows a calculated $\mathrm{x}^{2}$-value of 134.430 and a critical $\mathrm{x}^{2}$-value of 7.810 at 0.05 Alpha level for 3 degree of freedom. Since the calculated $\mathrm{x}^{2}$-value is greater than critical $\mathrm{x}^{2}$. The null hypothesis, "Occurrence of accidents is uniform throughout the day" is rejected. Thus, it indicates that the accidents are not uniformly distributed throughout the time.

\section{Identification of accident black spot}

i. Method uses for identification of accident black spot: Accident severity index, Accident density method and Weighted severity index (WSI)

ii. Weighted severity index (WSI): WSI follows a system of assigning scores based on the number and severity of accidents at that particular location. Severity of an accident is classified as Fatal (K), Grievous Injuries (GI) and Minor Injuries (MI).

WSI is calculated by formula,

$\mathrm{WSI}=(41 \times \mathrm{K})+(4 \times \mathrm{GI})+(1 \times \mathrm{MI})$

Where $\mathrm{K}=$ Number of persons killed

$\mathrm{GI}=$ Number of grievous injuries

$\mathrm{MI}=$ Number of minor injuries. 
Dipali R. Khamankar et al Int J Sci Res Sci \& Technol. March-April-2021, 8 (2) : 428-439

In the WSI formula a fatal accident has been given 10.02 times more weighted than grievous accident $(4<<41)$. Also, minor accidents have been given a unit coefficient $(1<41)$. For Grievous and Minor accidents to be comparable with fatal accidents.

TABLE XI

IDENTIFICATION, CAUSES AND PREVENTION OF BLACKSPOT

\begin{tabular}{|c|c|c|c|c|c|c|c|c|c|c|}
\hline $\mathrm{Sr}$ & $\begin{array}{c}\text { Name of } \\
\text { intersection }\end{array}$ & Fatal & $\begin{array}{l}\text { Grievous } \\
\text { Injuries }\end{array}$ & $\begin{array}{l}\text { Minor } \\
\text { Injuries }\end{array}$ & WSI & \multicolumn{2}{|c|}{$\begin{array}{c}\text { Causes of accidents and } \\
\text { damages }\end{array}$} & \multicolumn{2}{|r|}{ Improvements } & Remark \\
\hline \multirow{3}{*}{1} & \multirow{3}{*}{$\begin{array}{l}\text { Junona } \\
\text { Square }\end{array}$} & \multirow{3}{*}{7} & \multirow{3}{*}{3} & \multirow{3}{*}{5} & \multirow{3}{*}{304} & 1 & Over speeding & 1 & Provide Rumble strip & \multirow{3}{*}{ Blackspot } \\
\hline & & & & & & 2 & Pedestrian damages & 2 & Provide zebra crossing & \\
\hline & & & & & & 3 & Drunk and drive & 3 & $\begin{array}{l}\text { Checking of Alcohol } \\
\text { consumption level }\end{array}$ & \\
\hline \multirow{4}{*}{2} & \multirow{4}{*}{ Bangali Camp } & \multirow{4}{*}{6} & \multirow{4}{*}{8} & \multirow{4}{*}{16} & \multirow{4}{*}{294} & 1 & Uncontrol of vehicle & 1 & $\begin{array}{l}\text { Marking should be provide for } \\
\text { parking area }\end{array}$ & \multirow{4}{*}{ Blackspot } \\
\hline & & & & & & 2 & Crashes of vehicles & 2 & $\begin{array}{l}\text { Remove the illegal construction } \\
\text { at turning of road }\end{array}$ & \\
\hline & & & & & & 3 & Rush of pedestrians & 3 & $\begin{array}{l}\text { Taking necessary enforcement } \\
\text { action }\end{array}$ & \\
\hline & & & & & & 4 & Presence of potholes & & & \\
\hline \multirow{3}{*}{3} & \multirow{3}{*}{ Bagla Chowk } & \multirow{3}{*}{3} & \multirow{3}{*}{4} & \multirow{3}{*}{6} & \multirow{3}{*}{145} & 1 & Unsignalized area & 1 & Provide signals & \multirow{3}{*}{ Blackspot } \\
\hline & & & & & & 2 & Presence of pot holes & 2 & Remove pot holes & \\
\hline & & & & & & 3 & No road markings & 3 & Provide road marking & \\
\hline \multirow{3}{*}{4} & \multirow{3}{*}{ G.E.C. Square } & \multirow{3}{*}{2} & \multirow{3}{*}{3} & \multirow{3}{*}{7} & \multirow{3}{*}{101} & 1 & Absence of signal & 1 & Provide signal & \multirow{3}{*}{ Blackspot } \\
\hline & & & & & & 2 & $\begin{array}{l}\text { Improper } \\
\text { distribution of traffic }\end{array}$ & 2 & $\begin{array}{l}\text { Some sign boards are hidden due } \\
\text { to trees, make it visible. }\end{array}$ & \\
\hline & & & & & & 3 & $\begin{array}{l}\text { Due to hidden sign } \\
\text { board }\end{array}$ & & & \\
\hline \multirow{3}{*}{5} & & & & & & 1 & Due to pot holes & 1 & Remove pot holes & \\
\hline & Priyadarshani & 1 & 6 & 3 & 68 & 2 & $\begin{array}{l}\text { Improper divider } \\
\text { system }\end{array}$ & 2 & Provide proper dividing system & Blackspot \\
\hline & & & & & & 3 & $\begin{array}{l}\text { Due to crossing of } \\
\text { animals }\end{array}$ & 3 & $\begin{array}{l}\text { Provide restriction to unwanted } \\
\text { animals on road }\end{array}$ & \\
\hline & & & & & & 1 & $\begin{array}{l}\text { Absence of road } \\
\text { marking }\end{array}$ & 1 & Provide proper road marking & \\
\hline 6 & Bus Stop & 1 & 4 & 7 & 64 & 2 & No speed breakers & 2 & $\begin{array}{l}\text { Proper checking of signal should } \\
\text { be there }\end{array}$ & Blackenat \\
\hline 0 & Square & 1 & 4 & 1 & 04 & 3 & $\begin{array}{l}\text { Signal are situated } \\
\text { but it is off condition }\end{array}$ & 3 & Provide rumble strip & Blackspot \\
\hline & & & & & & 4 & $\begin{array}{l}\text { Road side traffic due } \\
\text { to auto }\end{array}$ & 4 & $\begin{array}{l}\text { Clearance of road traffic should } \\
\text { provide. }\end{array}$ & \\
\hline & & & & & & 1 & Presence of pot holes & 1 & Provide rumble strip & \\
\hline 7 & Gate & 1 & 3 & 2 & 55 & 2 & $\begin{array}{l}\text { Fast movement of } \\
\text { traffic }\end{array}$ & 2 & Remove pot holes & Blackspot \\
\hline 8 & Chota Bazar & 1 & 3 & 2 & 55 & 1 & $\begin{array}{l}\text { Opposite moving of } \\
\text { vehicle }\end{array}$ & 1 & Provide road marking & ot \\
\hline 8 & Square & 1 & 3 & 2 & כ5 & 2 & $\begin{array}{l}\text { Obstruction due to } \\
\text { auto stand }\end{array}$ & 2 & $\begin{array}{l}\text { Provide proper parking area for } \\
\text { auto stand }\end{array}$ & \\
\hline
\end{tabular}

\begin{tabular}{|c|c|c|c|c|c|c|c|c|c|c|}
\hline $\mathrm{Sr}$ & $\begin{array}{c}\text { Name of } \\
\text { intersection }\end{array}$ & Fatal & $\begin{array}{l}\text { Grievous } \\
\text { Injuries }\end{array}$ & $\begin{array}{l}\text { Minor } \\
\text { Injuries }\end{array}$ & WSI & & $\begin{array}{l}\text { auses of accidents } \\
\text { and damages }\end{array}$ & & Improvements & Remark \\
\hline \multirow{3}{*}{9} & \multirow{3}{*}{$\begin{array}{l}\text { Traffic } \\
\text { Office } \\
\text { Square }\end{array}$} & \multirow{3}{*}{1} & \multirow{3}{*}{2} & \multirow{3}{*}{3} & \multirow{3}{*}{52} & 1 & $\begin{array}{l}\text { Presence of pot } \\
\text { holes }\end{array}$ & 1 & $\begin{array}{l}\text { Median should be provided } \\
\text { for safe turning of vehicles }\end{array}$ & \multirow{3}{*}{ Blackspot } \\
\hline & & & & & & 2 & $\begin{array}{l}\text { Median is not } \\
\text { there }\end{array}$ & 2 & Remove pot holes & \\
\hline & & & & & & 3 & No traffic signals & 3 & $\begin{array}{l}\text { Proper signal should be } \\
\text { provided }\end{array}$ & \\
\hline 10 & Jayant & 1 & 0 & 2 & 43 & 1 & No proper road & 1 & Proper road marking should & Blackspot \\
\hline
\end{tabular}


Dipali R. Khamankar et al Int J Sci Res Sci \& Technol. March-April-2021, 8 (2) : 428-439

\begin{tabular}{|c|c|c|c|c|c|c|c|c|c|}
\hline & talkies & & & & & & marking & & be provided \\
\hline & Square & & & & & 2 & $\begin{array}{l}\text { Signals are in off } \\
\text { condition }\end{array}$ & 2 & $\begin{array}{l}\text { Rumble strip to be provided } \\
\text { to control the speed of } \\
\text { vehicles }\end{array}$ \\
\hline & & & & & & 3 & $\begin{array}{l}\text { Rumble strip are } \\
\text { not provided }\end{array}$ & 3 & $\begin{array}{l}\text { Maintenance of traffic signal } \\
\text { should be there }\end{array}$ \\
\hline & & & & & & 4 & $\begin{array}{l}\text { Number of pot } \\
\text { holes }\end{array}$ & 4 & Remove pot holes \\
\hline 11 & $\begin{array}{c}\text { Ram Nager } \\
\text { police } \\
\text { station } \\
\text { Square } \\
\end{array}$ & 0 & 2 & 7 & 15 & & & & \\
\hline 12 & Jatpura gate & 0 & 1 & 8 & 12 & & & & \\
\hline 13 & $\begin{array}{l}\text { Girnar } \\
\text { Square }\end{array}$ & 0 & 1 & 1 & 5 & & & & \\
\hline 14 & $\begin{array}{l}\text { Gandhi } \\
\text { Square }\end{array}$ & 0 & 0 & 3 & 3 & & & & \\
\hline
\end{tabular}

\section{iii. Causes of accidents and damages:}

1. Absence of road marking like center line, pavement edge lines.

2. Absence of traffic sign like, "major road ahead" in the minor road.

3. Condition of the pavement is not good.

4. Improper location of bus stops and auto stands.

5. Roadside parking of Lorries.

6. Violation of the traffic rules.

\section{iv. Recommendation and preventive measures:}

1. Need to provide road marking like center line, pavement edge lines.

2. Installation of "major road ahead" in the minor road.

3. Need of resurfacing of the pavement.

4. Re-location of bus stop and auto stands.

5. Prohibiting the roadside parking of Lorries.

6. Forcing the road users to follow the traffic rules.

\section{IV.RESULT}

WSI value are determined for the all 14 intersections. The locations with WSI value more than 40 are treated as accident black spots. 10 such locations are identified as a blackspot of Chandrapur city out of 14 intersections. After field observations and interaction with the public, some remedial measures are suggested for improvement of accident blackspots. There is no relationship between the severity of accidents and the other attributes like month, season, day, hours in day and the age group except type of vehicle. Road accidents are distributed throughout the year, month and season. Road accidents are not distributed throughout the day.

\section{v. CONCLUSION}

The study and analysis of accident at different intersection help in identifying the stretches were the accident are more and this spot reduce the road safety. The Weighted Severity Index (WSI) Method was used to rank the accident location. The black spot where selected as per the WSI having value more than 40 from the collected data and we had suggested suitable alternatives measures to reduce accident at such black spot. The overall methodology was found to be effective for identification, evaluation and treatment of accident black spot if sufficient data is available. Also found other factors such as non-availability of parking lane, lack of zebra crossing, lack of guard rails 
and also improper signal etc. It is also observed that most of the two wheelers users are not using the helmets and also over speeding their vehicles.

\section{REFERENCES}

[1]. Olusina, Jo; Ajanaku, WA Spatial analysis of accident spots using weighted severity index method (WSI) and density -based clustering algorithm, Department of Surveying and Geoinformatics, faculty of Engineering, University of Lagos, J. Appl. Sci. Environ. Manage. April 2017, vol. 21 (2) 397-403

[2]. Harsh Naik, Patel, Tazeen Pathan. "Identification and analysis of accident black spot on NH 147 using GIS”. Assistant professor of civil engineering department, Nirma University, Ahmedabad December 2016.

[3]. Athira mohan, Dr. V. S. Landge, "Identification of accident black spots on national highway". International journal of civil engineering and technology, 8(4), 2017, pp. 588-596

[4]. Liyamol Isen, Shibu A, Saran M. S. "Identification and analysis of accident black spot using geographic information system". Department of civil engineering and mechanical engineering of Rajiv Gandhi institute of technology, Kottayam, kerala India, vol. 2, December 2013

[5]. A. N. Dehury, A. K. Paattnaik, M. Panda, "Black spot analysis on National highways". Department of Civil Engineering, National Institute of Technology, Rourkela-769 008, Orissa, India, vol. 3 may-june 2013

[6]. Haffez and M. A. Kamal, "Accident Black spot on highways and their low-cost remedial measures". Department of civil engineering and technology, Taxila, Pakistan, WIT Transactions on the Built Environment, vol.101, 2008, ISSN 1743-3509

[7]. M Mohammed Fayaz, Mrudula S P, Sarah Jaison George, Sherin P Yoyak, Serin Sara Roy, "Black spot Identification using Accident Severity Index Method", Department of civil engineering, MITS Ernakulum, vol.5, Issue-3, 2018

[8]. Ferit Yakar, "Identification of accident-prone road sections by using relative frequency method", Gaziosmanpasa university, 60250 Tokat, Turkey

[9]. Arun Kumar, Ajay singh Chauhan, Abhishek Thakur, Khushpreet singh, "Black spot analysis on NH-21A", Department of civil engineering, Chandigarh university Gharaun -140413Punjab India, Indian journal of science and technology, vol.9(44) November 2016

[10]. Harnam Singh, A. D. Aggarwal, "Fatal road traffic accident among Young children", New delhi: jaypee bothers, 2006: p. 971-982

[11]. R. R. Sorate 1, R.P. Kulkarni, S. U. Babade, "Identification of accident black spot on national highway 4 (New Katraj tunnel to Chandani Chowk)" M.S. Patil, A.M. Talathi: I. Y. Sayyad4, S. V. Apte : IOSR Journal of Mechanical and Civil Engineering (IOSRJMCE), Volume 12, Issue 3 ver. I (May - June. 2015), PP 61-67

[12]. Vivek and Rakesh Saini, "Identification of accident black spots on national highway -3 district una, Himachal Pradesh - a case study" international journal of core engineering \& management (IJCEM) Volume 2, issue 3, June 2015.

[13]. Liyamol Isen, Shibu. A, Saran M. "Evaluation and treatment of accident black spot using geographic information system", International journal of innovative research in science, engineering and technology, ISSN: 2319-8753 vol. 2, issue 8, august 2013.

[14]. Ajit Goswami and Ripunjoy Sonowal. "A Statistical analysis of road traffic accidents in Dibrugarh city, Assam, India"

[15]. L. R. Kadiyali, Khanna Publications, Traffic engineering and transportation planning, 
[16]. L. R. Kadiyali and N. B. Lal, Khanna publications, Principles and practice of highway engineering

\section{Cite this article as :}

Dipali R. Khamankar, Dr. Prashant Y. Pawade, Dr. Bhalchandra V. Khode, "Accident Analysis and Blackspot Identification at Chandrapur City", International Journal of Scientific Research in Science and Technology (IJSRST), Online ISSN : 2395-602X, Print ISSN : 2395-6011, Volume 8 Issue 2, pp. 428-439, March-April 2021. Available at doi : https://doi.org/10.32628/IJSRST218264

Journal URL : https://ijsrst.com/IJSRST218264 